\title{
PERFORMANCE AUDIT MODEL OF INCENTIVE MEASURES IN SALE CHANNELS IN AGRICULTURAL HOUSEHOLDS OF THE REPUBLIC OF SERBIA
}

\author{
Jelica Eremić-Đođićl, Branislav Radnović ${ }^{2}$, Krsto Jakšic ${ }^{3}$ \\ *Corresponding author E-mail: jelica.eremic@ev.rs
}

A R T I C L E I N F O
Original Article
Received: 05 June 2020
Accepted: 18 August 2020
doi:10.5937/ekoPolj2003763E
UDC 657.631.8:658.8]:398.344
(497.11)

Keywords:

performance audit, sales channels, agricultural households, Republic of Serbia, incentive measures

JEL: Q13, M31, N74

\begin{abstract}
A B S T R A C T
Today, in modern business, all organizations and farms, are required to maximize organizational performance in order to achieve appropriate market success. In order to raise organizational performance to the maximum level, continuous monitoring of business activities and their results is necessary. They are monitored by internal control, ie internal audit. Within their sales channels, farms often set up their holdings without a predefined sales plan with well-defined costs. A constant obstacle to the marketing of agricultural products, in addition to the low price, is the high cost of realization. For this reason, the state tries to support the development of farms and promote the sale of agricultural products through various incentive measures. In order to evaluate how much these measures really contribute to its development, it is necessary to conduct a research on this topic and, based on the results of the research, to devise a model of the performance audit of incentive measures for sales channels of agricultural products which are produced on agricultural households of the Republic of Serbia. The abstract should contain a maximum of 150 words. The abstracts should avoid any abbreviations and mathematical formulas.
\end{abstract}

(C) 2020 EA. All rights reserved.

1 Jelica Eremić - Đođić, Ph.D., Assistant Professor, Educons University, Faculty for Business Economy, Novi Sad - Sremska Kamenica, Vojvode Putnika 87, 21208 Novi Sad - Sremska Kamenica, Phone: +381 648372 738, E-mail: jelica.eremic@ev.rs, ORCID ID (https:// orcid.org/0000-0003-2462-1672)

2 Branislav Radnović, Ph.D., Associate Professor, Educons University, Faculty for Business Economy, Novi Sad - Sremska Kamenica, Vojvode Putnika 87, 21208 Novi Sad - Sremska Kamenica, Phone: +381 611404 268, E-mail: profradnovic@gmail.com, ORCID ID (https://orcid.org/0000-0001-6888-6491)

3 Krsto Jaksic, Ph.D., Assistant Professor, Faculty of Economics, University in Pristina Kosovska Mitrovica, Kolasinska 156, 38220 Kosovska Mitrovica, Serbia, Phone: + 381 666662 811, E-mail: krsto.jaksic@pr.ac.rs;krsto.jaksic@gmail.com, ORCID ID (https:// orcid.org/0000-0001-5508-0069) 


\section{Introduction}

It has long been proven, both in science and in practice, that successful management requires the rationality and cost management.

In order to manage costs at all times, it is necessary to establish accurate and correct records. How today various organizations keep their records is left to every responsible person in an organizational institution to decide (when organizations are not subject to International Accounting Standards).

What is common for all forms of organization is that every investment must be justified and has its own purpose. Source of finance structure is one of the most important parameters which contribute to enterprise's profitability. There are a number of theories about relations between financial indebtedness and profitability, regarding the activity of given enterprise (agricultural activity, especially primary agricultural production has certain characteristics) (Vučković et al., 2017).

The common thing to all forms of organization is that every investment must be justified and must have its own purpose. Agroeconomic policy is an important part of the overall macroeconomic policy of every society (Milojević et al., 2019). Agricultural resources are of great importance for the Republic of Serbia. Since they are not used to their full extent, further investing in agriculture affects the overall economic development of Serbia (Milojević \& Mihajlović, 2019). This represents a significant economic potential for the future of the Republic of Serbia. In order to take full advantage of it, the state's investment in the agricultural sector needs to be controlled or monitored. This can only be done in one way: objectively and independently.

The influence of internal audit (IA) competency and independence and financial reporting quality (FRQ) has been confirmed by several researchers (see for example, Abbott et al., 2016; Prawitt et al., 2009). Today, business need more rationalization and reductions of operating costs. In the context of the mentioned rationalization and reduction of operating costs, today is more than ever essential to have good sales channels. Sales channels, or often called distribution channels, are just one of the elements of a marketing strategy that is very significant in the new business environment (Živković et al., 2019). Delivery of products or services to the consumer is done through sales channels. They are the link between the manufacturer and the consumers. Their goal is to ensure that the product or service reaches the consumer in the manner and location they are looking for (Andrei \& Darvasi, 2012). The only question is how to achieve the lowest possible cost and how to meet the requirements of the market. The role of traders in reducing search and transaction costs and in disseminating useful market information is widely recognized, both in farm (e.g. Banerji, Meenakshi, 2004; Miyata et al., 2009) and non-farm sectors (e.g. Sonobe et al., 2002).

Consequently, it is clearly concluded that every organization or farm, organizes its sales channels in the best possible way by providing the following answers: 
- How to market a product?

- the answer to this question is - to choose the right way of delivering products and / or services between direct and indirect distribution. It must be said immediately that each of the chosen methods of delivery of products and / or services has its advantages and disadvantages. Only through a detailed analysis the decision makers can decide on the way that suits their product / service, and above all the performance of the organization, which is most relevant.

-Where to market a product?

- the answer to this question is - to choose the right location (place) where a particular product and / or service will be offered to consumers. Choosing a location is not a naive business at all, and it influences the success of marketing products / services to consumers, that is, end users a lot.

-When to market a product?

- the answer to this question implies - to determine the right time (not just working time, although it is primarily meant) for the placement of products / services to consumers, or users to whom they are intended. Today, the answer to this question is only one thing: 24/7 because consumers have become spoiled, so they want their product or service to always be available to them.

In order to have accurate and timely information regarding the sale of products on the market, it is necessary to conduct a marketing research. Of course, processing one or two surveys is not enough. In order to have accurate and complete information, it is necessary to do continuous research (Kovačević et al., 2019).

Empirical research has shown the importance of markets that work well for efficient capital allocation (Wurgler, 2000). In order to be successful, it is important to focus on consumers.

Thus, dealing with customer relationships effectively has become vital to a firms' survival in today's competitive markets (Yen et al., 2015). This "dealing" with them will not be enough unless we build a strong business relationship. Maintaining ongoing relationships with customers is crucial for sustaining a competitive advantage (Kim et al., 2006). The reasons for this are multiple, but the most significant is the fact that it is less expensive to retain customers than to acquire new ones (Kim, Cha, 2002).

\section{Literature review}

Accordingly, the importance of agricultural holdings to the prosperity of the Republic of Serbia is not small. Recognizing this, the Republic of Serbia offered to agricultural holders certain forms of subsidies as forms of assistance in order to achieve multiple benefits for both parties. The results of this research will show if it succeed in its intention.

Two thirds of agriculture production value comes from plant production. Maize is the most important product, constituting about $25 \%$ of the total value of agricultural 
production. Thereby, the economic transformation process affected the livestock sector more significantly than the crop sector (Republic of Serbia IPARD Programme for 2014-2020, 2019).

In this regard, it is necessary to devise a way in which the said products will be marketed. Successful sales channels need to be designed.

In this volatile environment, channel teams are caught between the demand for better cost efficiency of channel sales and the need to drive partner engagement and productivity (8 Best Practices for Accelerating Revenue through Channels, 2018) .

In order to achieve the goal of maximum sale, it is necessary to devise methods to monitor the costs and results of their sales. Considering the lack of funds, which is widely represented in the field of agriculture, the state has recognized the importance of the private sector and has found a solution in integration with the public sector. Accordingly, it has decided to support its development through grants and to achieve multiple benefits for itself and the private sector.

\section{Materials and methods}

The management of an organization and agricultural household can be measured in many ways, but each of them aims at managing its costs. Accurate records represent the means by which this management can be accomplished. The way to achieve this is through adopted business rules, which can most often be based on the following methods:

- creating procedures and instructions,

- making the internal acts of business,

- implementation of financial management and control,

- establishing a solid control framework that can best identify, evaluate and eliminate risks in business, and more.

Every form of organizing that should have only one goal: justification of the investment or its performance. In order to achieve this, it is necessary to manage both the costs and the business.

Modern business terms tend to rationalize and reduce the cost of each farm so the sales channels play a big role. They represent one of the essential elements of a marketing strategy. In order to set up sales channels in the best possible way, that fully answers the questions of how, where and when to market the product, it is necessary for the farms to carry out continuous marketing research in practice. This is a way to find out the accurate and timely data that will be used to strengthen the internal control framework of the farm (Beke-Trivunac, 2019). Its strengthening is achieved by innovating the existing internal control and on the basis of the obtained facts by creating a completely new internal control in it. The assessment of the success of such an outcome is reflected in an internal audit, which is the next step. 


\section{Farm control system and sale channels}

The basis of a positive internal audit outcome is a solid and well-established internal control framework. Good controls can be built only where there are firm foundation in the organization based on business responsibility and rationality of decision makers, which is also the most important conditions for good management of all elements of marketing strategy, especially in the context of this work through the sales channels of agricultural households of the Republic of Serbia.

Agriculture in Serbia is characterized by a traditional and extensive character, with an area that defines farms as small and medium in terms of their economic capacity and size. In order to properly manage the farm, the right decisions need to be made. Every decision making is based on information. Whether we will solve the problem or make it even bigger depends on the reliability, accuracy and timeliness of the information received. This leads to the conclusion that only after carring out the qualitative external surveys, it is possible to establish good internal procedures that ensure accurate and timely reports on the basis of which the responsible person, ie. the holder of the farm, will conduct his business. Considering the prices, weather conditions, market laws, product placement, legal regulations, consumer requirements, data and information variable and not easily predictable, making decision without a secure basis like external research and recording with a properly defined internal procedure is no easy task for farmers. Based on the above, the need for such research came out.

There are households and family farms. In accordance with the Law on Agriculture and Rural Development (Official Gazette of the Republic of Serbia, no. 41/2009, 10/2013 - other law and 101/2016), Article 16, the family farm is the basic form of organizing agricultural production and depending on its economic strength is divided into:

1) commercial family farm;

2) non-commercial family farm (Law on Agriculture and Rural Development, "Official Gazette of RS", No. 41/2009, 10/2013 - other law and 101/2016, Article 16)

Regardless of the form of organizing farms, they are required to act rationally. All this influences the idea of taking steps and initiating certain measures in order to empower agricultural households through a particular financing model and become sustainable in the domestic and foreign markets.

In this regard, the goal of every farm (and family) is to create incentives. Article 9. of the same law states the following types of incentives:

1) direct incentives;

2) market incentives;

3) structural incentives (Law on Agriculture and Rural Development, "Official Gazette of RS", No. 41/2009, 10/2013 - other law and 101/2016, Article 6) 
In relation to the previous, the legislation specified more precisely two things:

1. when renewing the registration of an agricultural holding, it is necessary to give precisely the sowing plan for the next period

2. all fertile land must be incorporated within the household that the holder wants to cultivate.

\section{Research, presentation and analysis of research results}

In order to manage his property well,each owner or property holder has to establish internal controls for his business. In order for them to be properly defined and implemented, it is necessary to analyze the household. Therefore, the purpose of this research is to assess, on the basis of a feasibility audit, whether the incentives provided by the local self-governments to the agricultural holdings of the Republic of Serbia have succeeded in assisting them and to what extent they have become their source of funding. In this way, the agricultural households is developing, which affects the development of the Serbian agricultural, local self-government and Serbian economy in width as well.

Therefore, a Questionnaire was prepared whose results, after analysis, will serve to provide a model for reviewing the feasibility of incentive measures as a function of the farm sales channel.

For the proposed analysis of the research, it is necessary to find out the risk points for which special measures need to be prescribed, identified and thus put under control. In order to justify this practical analysis, a questionnaire was formulated with 43 questions that were a combination of open and closed questions. As for the closed questions, most of them were answered through the rating scale, where the answers were collected and ranked as follows ( 1 - worst grade, 5 - best grade):

$1-(0-20 \%)$

$2-(20-40 \%)$

$3-(40-60 \%)$

$4-(60-80 \%)$

$5-(80-100 \%)$

The questionnaire also contained several open-ended questions, where respondents the householders - were expected to answer their own questions in a few words or sentences. The questionnaire was sent to exactly 48 farms, with complete data returned by 34 farms, which represents a response rate of $70.83 \%$, and was considered significant in terms of the data obtained for processing, analysis and presentation of the survey results as well as the model proposal. The survey period was June - December 2019. The results were presented in the form of tables on the following pages. 
Table 1. The questionnaire with answers

\begin{tabular}{|c|c|}
\hline $\begin{array}{l}\text { Ordinal } \\
\text { number }\end{array}$ & Questions: \\
\hline 1. & $\begin{array}{l}\text { To what degree are you aware of the incentives you can take to support the production and } \\
\text { operation of your farm? } \\
1\end{array}$ \\
\hline 2. & $\begin{array}{l}\text { In what extent did you use the incentives directly? } \\
1\end{array}$ \\
\hline 3. & $\begin{array}{l}\text { Circle if and how much have you used the following forms of direct incentive? } \\
\text { • Bonuses } 12345 \\
\quad \text { Production incentives } 12345 \\
\quad \text { - Regress } 12345 \\
\text { • Non-commercial support for agricultural households } 1 \quad 2 \quad 3\end{array}$ \\
\hline 4. & $\begin{array}{l}\text { Are you satisfied with the amount of direct incentives? } \\
1\end{array}$ \\
\hline 5. & $\begin{array}{l}\text { Circle what form of direct incentive was successful in operating your own farm and in } \\
\text { what extent? } \\
\quad \text { - Bonuses } 12345 \\
\quad \text { Production incentives } 12345 \\
\quad \text { - Regress } 12345 \\
\quad \text { - Non-commercial support for agricultural households } 1 \quad 2 \quad 3 \quad 4 \quad 5\end{array}$ \\
\hline 6. & $\begin{array}{l}\text { Circle to what extent these incentives act as a stimulus to increase the production capacity } \\
\text { of your farm. } \\
1\end{array}$ \\
\hline 7. & To what extent have you used market incentives?1 \\
\hline 8. & 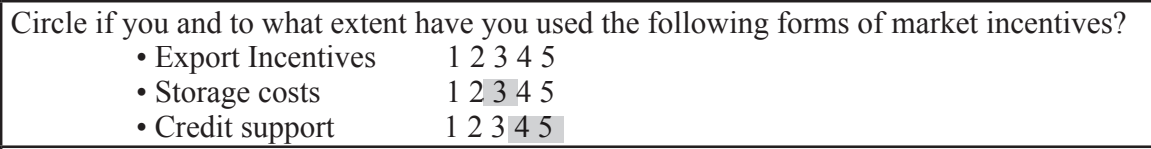 \\
\hline 9. & $\begin{array}{l}\text { Circle to what extent do you consider that the prescribed percentage obtained on export } \\
\text { incentives as a return on the value of exported goods is sufficient? } \\
1\end{array}$ \\
\hline 10. & $\begin{array}{l}\text { Circle the extent to which these market incentive measures act as a stimulus to increase the } \\
\text { production capacity of your farm. } \\
1\end{array}$ \\
\hline 11. & $\begin{array}{l}\text { Circle the extent to which these market incentive incentives act to stimulate you to } \\
\text { become more competitive in the market? } \\
1\end{array}$ \\
\hline 12. & $\begin{array}{l}\text { Circle the extent to which credit support as a type of incentive to encourage agricultural } \\
\text { and food production really helps farmers? } \\
1\end{array}$ \\
\hline 13. & $\begin{array}{l}\text { To what extent have you used structural incentives? } \\
1\end{array}$ \\
\hline
\end{tabular}




\begin{tabular}{|c|c|}
\hline $\begin{array}{l}\text { Ordinal } \\
\text { number }\end{array}$ & Questions: \\
\hline 14. & $\begin{array}{l}\text { Circle with what form of structural incentives and to what extent have you succeeded in } \\
\text { operating your farm? } \\
\text { - Rural development measures } 12345 \\
\text { - Improving protection and quality agricultural household } 12345 \\
\text { - Institutional support measures } 12345\end{array}$ \\
\hline 15. & $\begin{array}{l}\text { Circle the extent to which rural development measures have helped you achieve the } \\
\text { following: } \\
\text { - competitiveness in agriculture } 12345 \\
\text { - improving protection of the environment } 12345 \\
\text { - Conservation of biodiversity and programs of rural economics } 12345 \\
\text { - improving the quality of life in rural areas } 12345\end{array}$ \\
\hline 16. & $\begin{array}{l}\text { Circle the extent to which improvements to the protection and quality of households have } \\
\text { helped you to achieve the following: } \\
\text { - anti-erosion measures and measures of land inspection and testing } 12345 \\
\text { - land consolidation } 12345 \\
\text { - land reclamation } 122345 \\
\text { - recultivation } 12345\end{array}$ \\
\hline 17. & $\begin{array}{l}\text { Circle the extent to which institutional support measures have helped you: } \\
\text { - agricultural research } 12345 \\
\text { - advisory services } 12345 \\
\text { - promoting agriculture } 12345 \\
\text { - market information system } 12345 \\
\text { - professional services } 12345\end{array}$ \\
\hline 18. & \begin{tabular}{|l} 
How are you informed of incentive support measures?. \\
- Directly in the relevant institutions 12345 \\
- Through regulations 12345 \\
- Through local governments 12345 \\
• From other farmers 12345 \\
- Via media 12345 \\
- Other: internet 12345 \\
\end{tabular} \\
\hline 19. & $\begin{array}{l}\text { Evaluate to what extent is the public sufficiently informed about the incentives and how } \\
\text { they are used? } \\
12345\end{array}$ \\
\hline 20. & $\begin{array}{l}\text { Circle the degree of use of the statutory acts you use in your daily work in the farm? } \\
\text { - procedures: } 12345 \\
\text { - instructions: } 12345 \\
\text { - Regulations: } 12345 \\
\text { • Laws: } 12345 \\
\text { • other: } 12345 \\
\end{array}$ \\
\hline 21. & $\begin{array}{l}\text { Circle the degree of coverage of the farm work process by internal controls? } \\
12345\end{array}$ \\
\hline 22. & 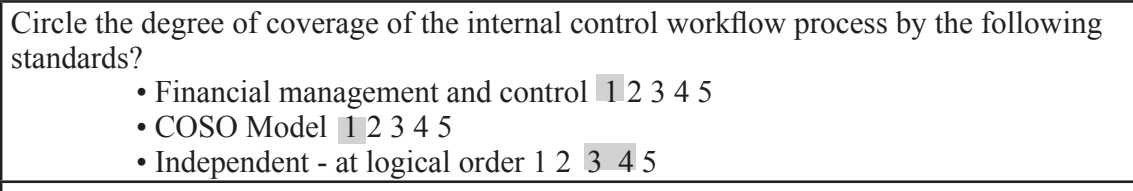 \\
\hline 23. & $\begin{array}{l}\text { Circle the level of training on financial management and control of farm employees? } \\
12345\end{array}$ \\
\hline
\end{tabular}




\begin{tabular}{|c|c|}
\hline $\begin{array}{l}\text { Ordinal } \\
\text { number }\end{array}$ & Questions: \\
\hline 24. & $\begin{array}{l}\text { Circle the level of training on ISO standards for farm employees? } \\
12345\end{array}$ \\
\hline 25. & $\begin{array}{l}\text { Circle the computer skills level of farm employees? } \\
\begin{array}{ll}2345\end{array}\end{array}$ \\
\hline 26. & $\begin{array}{l}\text { How secure is your farm management when choosing the type of incentive? } \\
12345\end{array}$ \\
\hline 27. & $\begin{array}{l}\text { To what extent has the leadership of your organization defined the criteria for selecting a } \\
\text { particular incentive measure? } \\
12345\end{array}$ \\
\hline 28. & $\begin{array}{l}\text { To what extent has your organization's management defined business risk? } \\
12345\end{array}$ \\
\hline 29. & $\begin{array}{l}\text { Evaluate the degree of assistance with incentives for agricultural machinery. } \\
12345\end{array}$ \\
\hline 30. & $\begin{array}{l}\text { Do you have a Risk Act? } \\
\text { 1. Yes } \\
\text { 2. No }\end{array}$ \\
\hline 31. & $\begin{array}{l}\text { Circle in response if you have received any training on the use of incentives } \\
\text { offered by the Republic of Serbia? } \\
\text { 1. Yes } \\
\text { 2. No }\end{array}$ \\
\hline 32. & $\begin{array}{l}\text { How do you monitor the running costs of your farm? } \\
\text { There is no established and accurate record. Accurate records are kept only by } \\
\text { those who are in the system of VAT. }\end{array}$ \\
\hline 33. & $\begin{array}{l}\text { Do you make any specific business reports for your farm? } \\
\text { Mostly only those who operate in the VAT system and are required to do so by } \\
\text { law. }\end{array}$ \\
\hline 34. & $\begin{array}{l}\text { Write which ones? } \\
\text { Rarely does anyone keep statistics, if not in the system of VAT; while larger } \\
\text { farms keep a modest record of available funds, consumption, profits. }\end{array}$ \\
\hline 35. & $\begin{array}{l}\text { What internal acts do you use in business? } \\
\text { They are not made. }\end{array}$ \\
\hline 36. & $\begin{array}{l}\text { Do you use any software to run your farm? } \\
\text { No. Mostly these are handy records. Larger farms use the windows operating } \\
\text { system (word and excel) for the most common reports. }\end{array}$ \\
\hline 37. & $\begin{array}{l}\text { What software do you use for the business of your farm? } \\
\text { Accountants only keep books for large farm holdings and those which are in the } \\
\text { VAT system. }\end{array}$ \\
\hline 38. & $\begin{array}{l}\text { To whom do you submit business reports for your farm? } \\
\text { the Treasury Directorate, only the records required for the VAT system and the } \\
\text { reports on earmarked assets. }\end{array}$ \\
\hline
\end{tabular}




\begin{tabular}{|l|l|}
\hline $\begin{array}{l}\text { Ordinal } \\
\text { number }\end{array}$ & \multicolumn{1}{c|}{ Questions: } \\
\hline 39. & $\begin{array}{l}\text { Do you provide incentive use reports? } \\
\text { No. Only the Treasury Directorate shall provide a resolution that an incentive } \\
\text { award has been made. }\end{array}$ \\
\hline 40. & $\begin{array}{l}\text { To which institution do you provide reports on the use of incentives? } \\
\text { Revenue Administration. }\end{array}$ \\
\hline 41. & $\begin{array}{l}\text { Did you have any control, if so, which one? } \\
\text { We have regular controls on the allocation of credit funds and how they are used. }\end{array}$ \\
\hline 42. & $\begin{array}{l}\text { Do you have a farm business plan? } \\
\text { 2. Yes }\end{array}$ \\
\hline 43. & $\begin{array}{l}\text { Have you acted in accordance with Article 3 of the Ordinance on entry in the } \\
\text { Register of agricultural holdings. Considering the renewal of registration, } \\
\text { as well as on the conditions for the passive status of an agricultural holding, } \\
\text { which stipulates that the holder of the agricultural holding is keeping a contract } \\
\text { on assignment of agricultural land for use, unless the contract expires before } \\
\text { October 31 for the current year? } \\
\text { 1. Yes } \\
\text { 2. No } \\
3 . \text { Partly }\end{array}$ \\
\hline
\end{tabular}

Source: Authors

Analyzing the answers from the questionnaire as the results of the research, we came to the following findings:

1. Holders of agricultural households are aware of the incentive measures offered by the Republic of Serbia as assistance in the development of agricultural activities, though grade ranging from 3 to 4 , which means that there are more those who follow the regulations and contribute to the effort in the development of agricultural holdings than those who do not;

2. It is also concluded that almost the highest grade (grade 4) of agricultural householders was rated when using these incentives;

3. The most used incentives were regresses (grade 5), followed by incentives for production (grade 4-5), then support for non-commercial farms (grade 3-4), and least bonuses (grade 3$)$;

4. When it comes to the amount of incentive measures, the survey showed dissatisfaction (grade 1).The measures of direct incentives are well designed, but the level of their amounts did not help them to succeed in the operations of agricultural households;

5. In this regard, research has shown that agricultural households holders consider that such incentive measures have a poor effect on direct incentives (grade 2). This is due to the lack of incentive to increase their production capacity; 
6. When it comes to market incentives, (respondents' ratings range between 3 and 4) which means that market incentives are used, but further analyzes will determine why they do not intersect in full;

7. Of all market incentives, the most commonly used market incentives are credit support (grade 4-5), while market incentives are used for storage costs (grade 3). We received answers regarding export market incentives from only a few respondents, so we did not include them in the analysis due to the validity of the research results. We will try to see the reason for this through the proposed model;

8. Market incentives, in the opinion of the respondents, act as a disincentive (grade 1-2) when it comes to market competitiveness and a potentially possible increase in production capacity;

9. Credit support (banks and other financial organizations) was rated more than satisfactory (grade 4-5);

10. Respondents rated the method of learning about incentive support measures as follows:

directly in competent institutions (grade 3-4)

o through regulations (grade 3)

o through local governments (grade 2)

o from other farmers (grade 4-5)

o via media (grade 4-5)

other: internet (grade 5)

confirming that the Republic of Serbia has found ways to inform the public and all market players sufficiently (in this case, agricultural households of the Republic of Serbia) about incentive funds and how they are used (grade 4-5);

A The greatest assistance of the Republic of Serbia (in the opinion of the respondents - the holders of agricultural holdings) is in the form of incentives for the purchase of new equipment or restoration of outdated agricultural machinery (grade 5);

A the survey showed that there are no established cost records, adopted internal acts, and no precise business plans for agricultural holdings (except for the sowing plan);

A Article 3 of the Rulebook on Registration in the Register of Agricultural Holdings and Renewal of Registration stipulates that the owner of the agricultural holding is keeping a contract on assignment of agricultural land for use, unless the contract expires before October 31 for the current year? According to which the majority of respondents only partially acted while there were a number of those who had not done that yet.The implementation of this Article of the Rulebook is necessary to incorporate into the model of the performance audit of incentive measures that will be in function of improving the sale channel of agricultural households of the Republic of Serbia. 


\section{Presentation of the model of performance audit of incentive measures in the function of the sale channels of agricultural holdings of the Republic of Serbia with the given internal control proposals and recommendation}

On the basis of the obtained results and detailed analyzes, a model of a performance audit for incentive measures in the function of the sale channels of agricultural households of the Republic of Serbia was developed and proposed, which contains the following steps:

- audit plan;

- identification of existing legislation;

- analysis of compliance of prescribed and adopted procedures, instructions and internal acts of agricultural holdings with legal regulations;

- recording of general performance and business situation of farms in the field in the Republic of Serbia;

- identification of risk points in the operations of farms;

- prescribing control measures for the risk points of agricultural holdings' operations, controlling and reducing the risk of doing business;

- implementation of measures in the internal acts and standards of business of farms;

- control of their implementation.

For each review, control or audit, regardless of its purpose, a plan must be drawn up. When it comes to the audit plan, there is a possibility that it may be altered during the engagement when any unplanned problems occur or when areas requiring smaller or larger audit work are identified during the assessment of the reliability of internal controls (Andrić et al., 2012).

In order to create a model for reviewing the performance of incentive measures in the function of the farm sale channels of the Republic of Serbia, it is necessary to point out some of the answers received from the Questionnaire, which at the same time represent their potential risk points:

- insufficient level of assistance for rural development measures in:

o competitiveness in agriculture (grade1)

o Improvement of the environmental protection program (grade 1)

o Conservation of biodiversity and programs of rural economics (grade 1)

o improving the quality of life in rural areas (grade 1)

- insufficient degree of improvement of protection and quality of agricultural land:

o anti-erosion measures and measures of land inspection and testing (grade 1) 
o land consolidation (grade 1)

o reclamation (grade 3 ) - average

o recultivation (grade1-2)

- insufficient level of institutional support in specific segments:

o agricultural research (grade 1)

o advisory services (grade 1-2)

- lack of prescribed procedures and instructions as internal acts for working in the daily business processes of agricultural holdings (grade 1);

- insufficient coverage of farm operations in internal controls according to the following standards (grade 1):

o financial management and control,

o according to the COSO model,

o even at its sole discretion (grade 3-4);

- insufficient IT skills and technical support reflected through the underused of software packages and individual windows office programs (even word and excel).

Risk in business leads to uncertainty and it must be put under control. Risk management is the process of identifying, assessing, managing and controlling potential events or situations in order to provide a reasonable degree of assurance about the achievement of the organization's goals (Stanišić, 2015). Therefore, based on the results of the research, this takes into account the risk points of the farm business. Risk assessment should be carried out regularly, every 12 to 24 months (Singleton et al., 2006).

In accordance with the above model of the performance audit of incentive measures in the function of the sale channel of agricultural households of the Republic of Serbia, it is necessary to include the following elements that make up the subject of the audit procedure:

- Comply with the legal obligation to implement the sowing plan - it is essential that the sowing plan is fully complied, when restoring the farm.

Internal control 1.: in case of necessary modification of the sowing plan, it is necessary to fill in the form and submit it to the competent authority for inspection. It is necessary for the farm to always prepare an up-to-date internal report and submit the complete documentation to the accountant in charge of the farm.

- Comply with the legal obligation that all fertile land must be incorporated within a registered agricultural household.

Internal control 2.: for all fertile land for which incentives and assistance from the state are sought, it is necessary to be legally based and recorded in the farm records. Moreover, each parcel must have a proof of ownership (leasehold) or lease agreement. 
It is therefore necessary to introduce an always up-to-date internal report with the following elements:

Table 2. Recommended internal report for agricultural households

\begin{tabular}{|c|c|c|c|c|c|c|c|c|}
\hline $\begin{array}{c}\text { Farm } \\
\text { Numb } \\
\text { er - }\end{array}$ & $\begin{array}{c}\text { Cada } \\
\text { stral } \\
\text { muni } \\
\text { cipali } \\
\text { ugric } \\
\text { ultura } \\
\text { l }\end{array}$ & $\begin{array}{c}\text { Legall } \\
\text { ty } \\
\text { bindin } \\
\text { gouse } \\
\text { hold } \\
\text { (AH) }\end{array}$ & $\begin{array}{c}\text { Parce } \\
\text { docu } \\
\text { ment } \\
\text { (entry } \\
\text { no. / } \\
\text { ber }\end{array}$ & $\begin{array}{c}\text { Name and } \\
\text { surname } \\
\text { of the } \\
\text { owner of } \\
\text { the parcel } \\
\text { agree } \\
\text { ment) }\end{array}$ & $\begin{array}{c}\text { Categoriz } \\
\text { ation of } \\
\text { agricultur } \\
\text { al land }\end{array}$ & $\begin{array}{c}\text { The } \\
\text { crop } \\
\text { from } \\
\text { the } \\
\text { sowin } \\
\text { g plan }\end{array}$ & $\begin{array}{c}\text { Sowed } \\
\text { crop }\end{array}$ & $\begin{array}{c}\text { Name and } \\
\text { surname } \\
\text { of the } \\
\text { farm } \\
\text { owner } \\
\text { (AH)- } \\
\text { Agricultu } \\
\text { ral } \\
\text { household }\end{array}$ \\
\hline 1 & 2 & 3 & 4 & 5 & 6 & 7 & 8 & 9 \\
\hline & & & & & & & &
\end{tabular}

Source: Authors

The attached table is the primary basis control for the fulfillment of the legal requirements regarding the status of the agricultural holding, whose up-to-date application provides daily insight into all the necessary information.It is important not to deviate from the basic conditions for the fulfillment of the active status of the agricultural holding and to prevent the possibility of obtaining government incentives.

- Internal control 3. : since there is no established record of the earmarked use of incentive funds (except for loans granted by banks), we propose to include the following binding records in the farm business:

Table 3. Recommended report for the agricultural households no.2

\begin{tabular}{|c|l|l|l|l|c|l|l|l|}
\hline $\begin{array}{l}\text { Pur- } \\
\text { pose of } \\
\text { Incen- } \\
\text { tives }\end{array}$ & $\begin{array}{l}\text { The } \\
\text { amount } \\
\text { of ap- } \\
\text { proved }\end{array}$ & $\begin{array}{l}\text { Ap- } \\
\text { proval } \\
\text { date }\end{array}$ & $\begin{array}{l}\text { Num- } \\
\text { ber } \\
\text { of } \\
\text { users }\end{array}$ & $\begin{array}{l}\text { Amount } \\
\text { spent }\end{array}$ & $\begin{array}{l}\text { Purpose } \\
\text { of spent }\end{array}$ & $\begin{array}{l}\text { Balance } \\
\text { of } \\
\text { the re- } \\
\text { maining } \\
\text { funds } \\
\text { (saldo) }\end{array}$ & $\begin{array}{l}\text { Reason } \\
\text { for un- } \\
\text { spent }\end{array}$ & $\begin{array}{l}\text { Effect of } \\
\text { utilization } \\
\text { through the } \\
\text { sale channels }\end{array}$ \\
\hline 1 & 2 & 3 & 4 & 5 & 6 & $7=(2-5)$ & 8 & 9 \\
\hline & & & & & & & &
\end{tabular}

Source: Authors

- Recommendation 1 : Many computer based educational programs have been appeared lately. At the same time, "there are numerous benefits of computer training, videos and the Internet. They are:

determining your own pace (students can learn at their own pace), consistency of teaching (every student, whether they attend the course now or not, receives instruction of the same quality), portability (trainees can take the material with them, access it online or have it delivered to a branch) and price (the cost per attendee is further reduced 
each time more employees from the same organization attend the course (Coderre, 2009)). All of this goes into the audit recommendation included in this model in order to increase the internal performance of the farm itself and increase the utilization and effects of the earmarked funds as well.

This method of recording funds enables the monitoring of the use of earmarked funds with the traceability of its documented basis. Apart from the farm as the beneficiaries of the incentive funds and the state as the donor, they have full insight into the performance of spending the funds.

\section{Discussion}

This paper represents the basis for future research regarding the implementation of a new control framework, with the help of which the operations of agricultural holdings and its costs are put under control. Consequently, this paper provides answers to the unresolved problems encountered in literature and practice and serves as a setting for new procedural rules and business controls created for the purpose of performance audit in agricultural households.

\section{Concluding considerations}

The global market competition requires each country to constantly improve the economic capacity of its own economic. One of the most expansive industries and the backbone of each country's economic development is agriculture.

Today, more than ever, healthy food is being sought, and in connection with the same a healthy agricultural product.

Healthy agricultural production requires the use of clear, precise and above all effective agroeconomic measures and incentives, as well as adequate utilization of them, not only based through production but also through the sale of the same, ie. delivering them through sale channels to end users - consumers.

The analyzes that preceded this paper show that there are significant deviations from the incentive measures that have been given and the usefulness of the same through the farm sale channels. In this regard, it was also noted the necessity to conduct such a survey, which would provide clear answers regarding the required model of the performance audit of incentive measures in the function of the sale channels of agricultural farms of the Republic of Serbia, which would put incentives for agricultural holdings under greater control.

Recommended model given in point 4 of this paper and based on the presented risk points:

1. adherence to the sowing plan in order not to lose the active status of AH and all approved state incentives;

2. consolidation of fertile land in $\mathrm{AH}$, as well as documenting the right to own it; 
3. accurate records of the intended use of the incentive funds and the effects viewed through the sales channels; were formed.

and 3 (three) additional and significant internal controls and one recommendation

The recommendation is based on perceived ignorance, lack of interest and inadequate information of potential beneficiaries of incentive measures.

That is why one recommendation is given, which is a mandatory part of the model of the performance audit of incentive measures in the function of the sale channel of agricultural households of the Republic of Serbia, and relates to greater IT skills and literacy.

On the basis of all the above, we think and suggest that all agricultural enterprises operating in the territory of the Republic of Serbia, should implement this model or partially modified of performance audit. By doing that they would achieve better management of not only sale channels, but also better management of the overall marketing management strategy, and thus achieve greater market success.

In this way, in the context of their business, besides being able to look at the utilization of earmarked spending, farms can also see the effect of their utilization in terms of the sale channels of agricultural products.

It is evident that the benefits of this model are both for agricultural households as beneficiaries of purposefully given funds, and the state of the Republic of Serbia as the provider of those whose legal obligation it is.

\section{Conflict of interests}

The authors declare no conflict of interest.

\section{References}

1. Abbott, L., Daugherty, B., Parker, S., \& Peters, G. (2016). Internal audit quality and financial reporting quality: the joint importance of independence and competence. Journal of Accounting Research, 54(1), 3-40. doi: https://doi.org/10.1111/1475679X.12099

2. Andrei, J. V., \& Darvasi, D. (2012). Perspectives and challenges in financing the new Common Agricultural Policy, a new paradigm. Journal of Food, Agriculture \& Environment, 10 (1 part 2), 904-907.

3. Andrić, M., Krsmanović, B., \& Jakšić, D. (2012). Revison - theory and practice; University of Novi Sad, Faculty of economics, Subotica [in Serbian: Andrić, M., Krsmanović, B. \& Jakšić, D. (2012). Revizija, teorija i praksa, Univerzitet u Novom Sadu, Ekonomski fakultet Subotica]. 
4. Banerji, A., \& Meenakshi, J.V. (2004). Millers, commission agents and collusion in grain auction markets: evidence from basmati auctions in north India, Working Paper No. 129, Centre for Development Economics, Delhi School of Economics, New Delhi, (available at: www.cdedse.org/pdf/work129.pdf, accessed January 29, 2020).

5. Beke-Trivunac, J. (2019). Knowledge and competences attained by certification Certified Internal Auditor (CIA). Oditor - Časopis za menadžment, finansije $i$ pravo, 5(1), 53-69. doi: https://doi.org/10.5937/Oditor1901053B

6. Coderre, D. (2009). Internal Audit, - Efficiency through Automation, Serbian Alliance of Accountants and Revisors, Belgrade [in Serbian: Coderre, D. (2009). Интерна ревизија, Аутоматизачијом до ефикансости, Savez računovođa i revizora Srbije, Beograd].

7. Kim,W.G., \& Cha,Y. (2002). Antecedents and consequences of relationship quality in hotel industry. International Journal of Hospitality Management, 21(4), 321338. doi: https://doi.org/10.1016/S0278-4319(02)00011-7

8. Kim,W.G., Lee,Y.K., \& Yoo,Y.J. (2006). Predictors of relationship quality and relationship outcomes in luxury restaurants. Journal of Hospitality and Tourism Research, 30(2), 143-169. doi: https://doi.org/10.1177/1096348005285086

9. Kovačević, M., Trandafilović, J., \& Kalač, D. (2019). Audit aspect of execution of the budget. Oditor - Časopis za menadžment, finansije i pravo, 5(1), 93-105. doi: https://doi.org/10.5937/Oditor1901091K

10. Law on Agriculture and Rural Development, "Official Gazette of RS”, No. 41/2009, 10/2013 - other law and 101/2016).

11. Milojević, I., Ignjatijević, S., \& Ćurčić, M. (2019). Integral Account And Agroeconomic Application Of An Introductory Integral. Economics of Agriculture, 66(2), 579-589. doi: https://doi.org/10.5937/ekoPolj1902579M

12. Milojević, I., \& Mihajlović, M. (2019). Implementation of the method of assessing investment projects in the public sector. Oditor - Časopis za menadžment, finansije i pravo, 5(1), 19-31. doi: https://doi.org/10.5937/Oditor1901019M

13. Miyata, S., Minot, N. \& Hu, D. (2009). Impact of contract farming on income: linking small farmers, packers, and supermarkets in China, World Development, 37 (11), 1781-1790.

14. Model N Headquarters, (2018). 8 Best Practices for Accelerating Revenue through Channels, Whitepaper, San Mateo, California, USA, Retrieved from https://www. modeln.com/wp-content/uploads/2017/07/wp_8_best_practices_for_accelerating revenue.pdf (March 13, 2020).

15. Prawitt, D., Smith, J., \& Wood, D. (2009). Internal audit quality and earnings management, The Accounting Review, 84(4), 1255-1280. doi: https:/doi. org/10.2308/accr.2009.84.4.1255 
16. Republic of Serbia IPARD Programme for 2014-2020, (2019). Ministry of Agriculture and Environmental Protection Republic of Serbia, third modification 2019, Retrieved from http:/uap.gov.rs/wp-content/uploads/2017/11/IPARDIIfinal-III-modification-ENG27062019.pdf (February 21, 2020).

17. Singleton, T.W., Singleton, A.J, Bologna, J., \& Lindquist, R. (2006). Fraud Auditing and Forensic, Serbian Alliance of Accountants and Revisors, Belgrade [in Serbian: Singleton,T.W., Singleton, A.J, Bologna, J. \& Lindquist, R. (2006). Revizija kriminalne radnje i forenzičko računovodstvo, Savez računovođa i revizora Srbije, Beograd].

18. Sonobe, T., Hu, D., \& Otsuka, K. (2002). Process of cluster formation in China: a case study of a garment town. Journal of Development Studies, 39 (1), 118-139. doi: https://doi.org/10.1080/00220380412331322691

19. Stanišić, M. (2015), Internal control and audit, University of Singidunum, Belgrade, [in Serbian: Stanišić, M. (2015). Interna kontrola i revizija, Univerzitet Singidunum, Beograd].

20. Yen, C.H., Liu, L.L., Chen, C.Y., \& Lee, T.Y. (2015). Customer relational benefits and relationship-marketing outcomes: comparing three transaction types of travel product. Asia Pacific Journal of Tourism Research, 20 (2), 171-190. doi: https:// doi.org/10.1080/10941665.2013.877042

21. Vučković, B., Veselinović, B., \& Drobnjaković, M. (2017). Financing of Permanent Working Capital In Agriculture, Economics of Agriculture, 64(3), 1065-1081. doi: https://doi.org/10.5937/ekoPolj1703065V

22. Wurgler, J. (2000). Financial markets and the allocation of capital. Journal of Financial Economics, 58(1-2), 187-214. doi: https://doi.org/10.1016/S0304405X(00)00070-2

23. Živković, A., Pantić, N., \& Rosić, M. (2019). Fiscal sustainability of the macroeconomic system of European Union members. Oditor - Časopis za menadžment, finansije $i$ pravo, 5(2), 32-41. doi: https://doi.org/10.5937/ Oditor1902033Z 